\title{
K POČIATKOM ARCHÍVU SLOVENSKÉHO NÁRODNÉHO MÚZEA. PRÍSPEVOK K ŽIVOTU A DIELU MÁRIE JERŠOVEJ OPOČENSKEJ
}

\author{
Elena Machajdíková
}

The Beginning of the Slovak National Museum Archives. The Life and work of Mária Jeršovská Opočenská

\begin{abstract}
The cultural heritage of the nation is protected by memory institutions, which consist, largely, of museums. One of the largest cultural institutions in Slovakia is the Slovak National Museum. Its archive has become a permanent source of information both on the institutional development of this longest continuously operating national cultural institution and the development of museum management in Slovakia. The article provides a brief overview of accessible archival sources on the history of the Slovak National Museum and, moreover, recalls the merits of some important personalities from the Czech Republic working in the field of preservation for Slovakia's cultural heritage.
\end{abstract}

Keywords: Slovak National Museum Archives - Mária Jeršová Opočenská - archival documents - the city of Martin

Contact: Archív Slovenského národného múzea v Bratislave, Žižkova ul. 18, P. O. BOX 13, 81006 Bratislava, Slovensko;

elena.machajdikova@snm.sk

Úvod

Kultúrne dedičstvo národa ochraňujú pamätové inštitúcie, medzi ktorými dominujú i múzeá. Jednou z najstarších a najväčších kultúrnych inštitúcií na Slovensku je Slovenské národné múzeum (d’alej len SNM). Sústred'uje autentické hmotné a písomné pramene $\mathrm{z}$ oblastí prírodných a spoločenských vied. SNM sa postupne stalo centrom vedeckého života, k čomu prispievali aj jeho archívne fondy a archívne zbierky. ${ }^{1}$ Archív Slovenského národného múzea (d’alej len Archív SNM) sa stal trvalým zdrojom informácií o inštitucionálnom vývoji našej najdlhšie kontinuálne pôsobiacej národnej kultúrnej inštitúcie ako i rozvoji múzejníctva na Slovensku. Výrazne sa o to zaslúžila pražská rodáčka Mária Jeršová Opočenská.

Národné múzeum založili koncom 19. storočia (1893) predstavitelia uvedomelej slovenskej inteligencie v Martine. $V$ tom čase bolo jediným miestom vedeckého skúmania a poznávania minulosti. Hlavným ciel'om múzea bolo zhromažd'ovat' pamiatky, ktoré by dokumentovali starobylost' kultúry Slovákov, ale dokazovali i jej rovnocennost' s kultúrou ostatných národov Európy. Odvtedy prešlo Slovenské národné múzeum zložitým vývojom. Jeho viac ako 4 miliónové pramenné bohatstvo dnes dokumentuje kultúru a život Slovákov doma aj v zahraničí. V predkladanom príspevku sa snažíme podat' nielen stručný prehl'ad o prístupných archívnych prameňoch $\mathrm{k}$ dejinám Slovenského národného múzea, ale našim úsilím je aj vyzdvihnút' vzájomnú spoluprácu predstavitel'ov českej a slovenskej kultúry a vedy po vzniku spoločného štátu a pripomenút pritom zásluhy niektorých významných osobností z Čiech pôsobiacich v oblasti záchrany kultúrneho dedičstva Slovenska. Kráčat' dejinami spoločne, či už vedl'a seba alebo v spoločnom štáte, predurčovalo pre obidva naše národy ich geografické susedstvo a jazyková príbuznost'. Stalo sa tak po skončení prvej svetovej vojny, kedy rozpadom Rakúsko-Uhorska 28. októbra 1918, vytvorili spoločný štát. Pre slovenský národ začala nová éra v jeho dejinnom vývoji vo všetkých oblastiach života, teda aj v tom múzejnom.

\section{Začiatky v spoločnom štáte}

Na území Slovenska do roku 1918 pôsobilo už spomínané Slovenské národné múzeum v Martine ${ }^{2}$ i niekol'ko mestských a župných múzeí. V podmienkach spoločného štátu začali Slováci sprístupňovat' kultúru a vedu širokým vrstvám spoločnosti prostredníctvom novozakladaných múzeí. V Bratislave napríklad založili Slovenské vlastivedné múzeum, Zemedelské múzeum, Lesnícke a lovecké múzeum (ich zlúčením neskôr vznikol ich právny nástupca - Slovenské

\footnotetext{
1 Pozri https://www.snm.sk/?zakladne-informacie.

2 Názov Slovenské národné múzeum sa začalo používat' od roku 1928.
} 


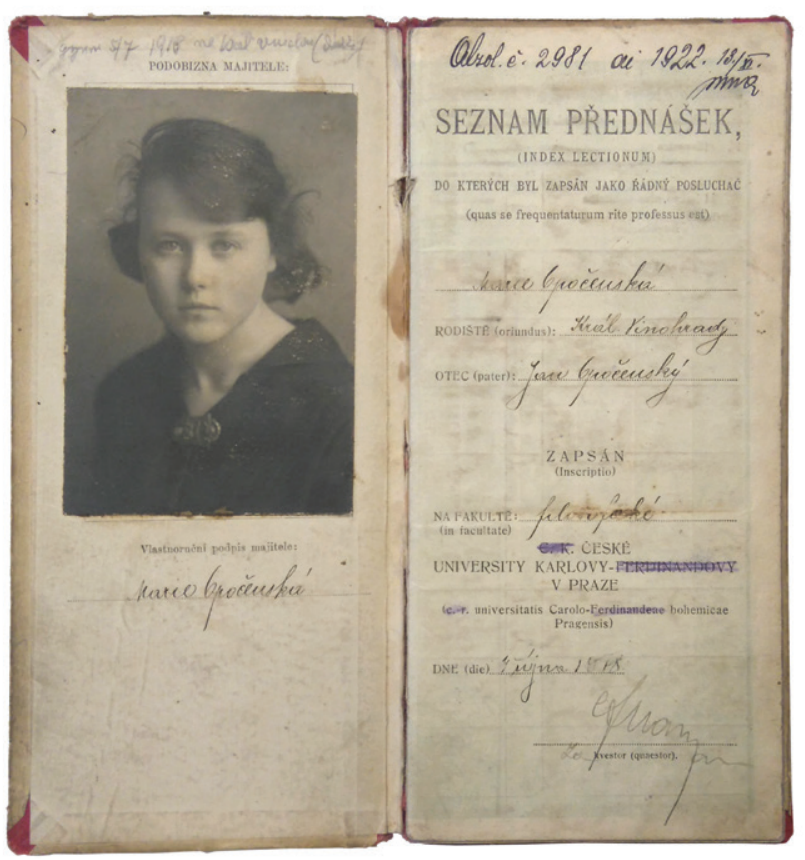

Obr. 1. Index Márie Opočenskej. Praha 8. októbra 1918. Archív SNM, pobočka v SNM-Múzeách v Martine. Fond M. Jeršová, sign. $\mathrm{MJ} / \mathrm{l}$.

múzeum). V príspevku sa budeme venovat' predovšetkým týmto múzeám a ich osobnostiam, ktoré boli priamymi predchodcami dnešného Slovenského národného múzea.

Slovenské vlastivedné múzeum konštituovali v roku 1923 ako muzeálny spolok zameraný na históriu a živú i neživú prírodu Slovenska. Členskú základňu tvoril kolektív vedeckých i radových pracovníkov z kultúrnych inštitúcií, najmä Univerzity Komenského v Bratislave. Zbierky múzea, ktoré získavali predovšetkým z výskumov, darov, depozitov, neskôr i nákupov, boli z oblasti spoločenskovedných a prírodných vied. Dodnes mnohé tvoria základ zbierkového fondu Slovenského národného múzea v Bratislave a niektorých d’alších inštitúcií.

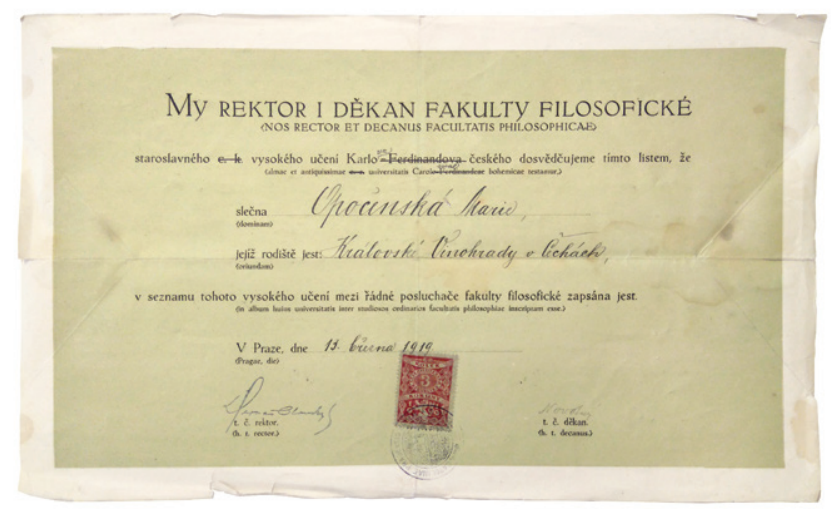

Obr. 2. Potvrdenie rektora Filozofickej fakulty Vysokého učení Karlova českého o prijatí Márie Opočenskej za riadnu poslucháčku, Praha 13. marca 1919. Archív SNM, pobočka v SNM-Múzeách v Martine. Fond M. Jeršová, sign. MJ/I.

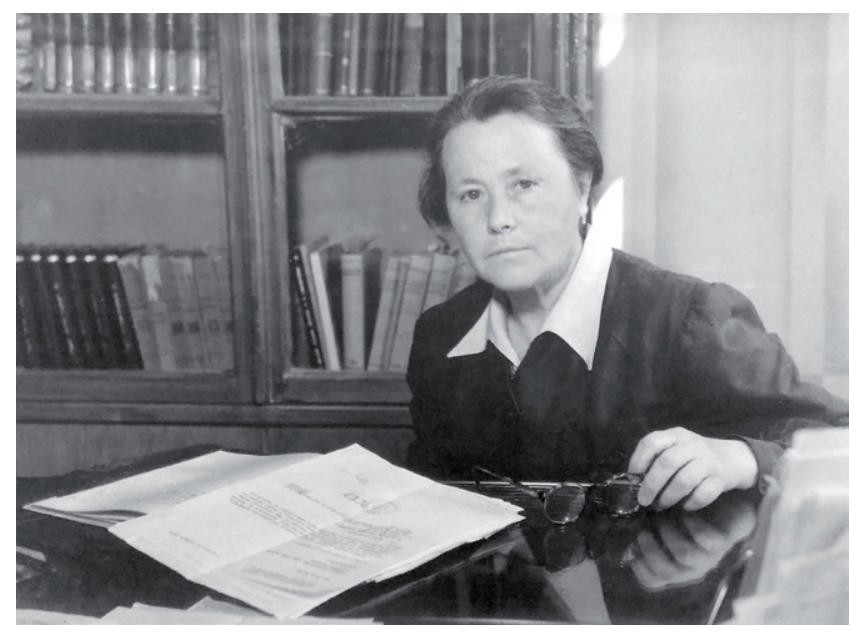

Obr. 3. Mária Jeršová Opočenská

Bratislava sa v roku 1924 stala aj sídlom novovybudovaného pol'nohospodárskeho múzea s názvom Zemedelské múzeum (1924-1940). Bolo krajinskou pobočkou pražského Československého zemědělského múzea (ústavu pro studium a povznesení venkova). Patrilo $\mathrm{k}$ špecializovaným múzeám, ktoré sa venovalo histórii a súčasnosti pol'nohospodárstva. Jeho autonómnou súčast'ou sa v roku 1927 stalo Lesnícke a lovecké múzeum. Obe múzeá riadili kuratóriá a ich činnost' schval'ovali valné zhromaždenia.

Hned' po vzniku Československej republiky začali prichádzat' na pomoc slovenskej kultúre odborníci z Čiech. Vo väčšej miere to umožnila neskôr aj úprava stanov Muzeálnej slovenskej spoločnosti (d'alej len MSS) v roku 1928. Členmi MSS sa odvtedy mohli stat' aj uchádzači z Čiech a Moravy. Za členov sa prihlásili múzejníci, vedci, architekti, učitelia, spisovatelia, študenti a iní (napríklad: Alois Jirásek, Lubor Niederle, František Pastrnek, Jan Eisner, Jiří Horák, Jaroslav Böhm, Václav Chaloupecký a mnohí d’alší), kolektívne členstvo tvorili i spolky, napríklad: Spolok mládeže Detvan v Prahe, Č́tárna akademického domu Praha, Umělecká beseda Praha, Vysoká škola archivní Praha, Archív hlavního města Prahy, Múzejní spolek Kouřim, Ústř̌ední sdružení Čechů a Slováků z Ruska a d'alšie. ${ }^{3}$

Úspešný rozvoj spomínaných múzeí bol narušený postupným zhoršovaním sa politickej a hospodárskej situácie vo svete a najmä v Európe. Následkom mníchovskej dohody 29. septembra 1938 sa Československá republika rozpadla. Rozdelenie štátnych útvarov na tzv. Slovenský štát a Protektorát Čechy a Morava 14. marca 1939 malo za následok rozdelenie múzejných ústavov.

Vplyvom rozdelenia štátu bola ekonomická situácia múzeí alarmujúca, ale okamžité riešenia si vyžadovala i personálna otázka. Slovenská vláda ju totiž riešila novými zákonnými opatreniami, ktoré mali za následok odchod členov českej národnosti aj z bratislavských múzejných spolkov. V bratislavských múzeách a kuratóriách pôsobili od roku 1919, vzniku ČSR, až do prelomu rokov 1938/1939 a ich podiel na práci múzea a odbornej realizácii nových expozícií bol nemalý.

3 Eva Králiková, Významné medzníky spolupráce českých a slovenských bádatelov koncom 19. a začiatkom 20. storočia. „Rodom Čech, duchom Slovák... “, Zborník Slovenského národného múzea. Etnografia 44, roč. XCVII - 2003, Martin 2003, s. 25-34. 
Zo Slovenského vlastivedného múzea odišli - archeológovia: Jan Eisner, zakladatel' antropologických zbierok, Vojtech Ondrouch - zaoberajúci sa rímskymi pamiatkami, historik Vladimír Klecanda, numizmatik Rudolf Machek, ako aj Antonín Václavík a Štefan Pražák vykonávajúci národopisný výskum, z prírodovedcov to boli Vladimír Balthazar, Antonín Frank, Zdeněk Frankenberger, František Pauk, a Klement Ptačovský ako aj spolupracovník Jan Roubal. Rady Kuratória Zemedelského múzea musel opustit' jeho konatel' Jan Kratochvíl, pokladník Emil Napravil, ako aj revízor zbierok František Vřeský. ${ }^{4}$ Z Muzeálnej slovenskej spoločnosti a martinského Slovenského národného múzea sa vrátili do rodných Čiech a na Moravu napríklad tajomník MSS a kustód botaniky Václav Vraný a Rudolf Řetovský, archeológovia Vojtech Budinský - Krička, Jaroslav Bőhm, Peter Mendel a Jozef Skutil, numizmatik Gustav Skalský, historici umenia Jan Hofmann a František Žákavec, antropológ Jiří Malý, odborníci z oblasti entnografie ako Vilém Štech, Jaroslav Pospíšil, František Kretz, či archivár Václav Vojtíšek a d'alšsi. ${ }^{5}$

Politické zmeny na Slovensku v rokoch 1938 a 1939 boli príčinou zložitej situácie spôsobenej aj pretrvávajúcim nedostatkom finančných prostriedkov, pričom riešením bolo zlúčenie troch múzeí s podobným zameraním a pôsobiacich $\mathrm{v}$ jednom priestore. Slovenské vlastivedné múzeum, Zemedelské múzeum a Lesnícke a lovecké múzeum sa v súlade s rozhodnutím vlády Slovenskej republiky z 26. januára 1940 zlúčili do jednej inštitúcie s názvom Slovenské múzeum. Slovenské národné múzeum v Martine pôsobilo v tom čase samostatne.

\section{Počiatky Archívu SNM}

V súvislosti s budovaním archívnych fondov a zbierok a sprístupňovaním archívneho bohatstva SNM v Martine a na Slovensku, je potrebné vyzdvihnút' Máriu Jeršovú Opočenskú, archivárku Muzeálnej slovenskej spoločnosti v Martine, respektíve Slovenského národného múzea. MSS už od svojho založenia 24 . apríla 1893 plnila aj poslanie slovenskej vedeckovýskumnej inštitúcie, nahrádzala zrušenú Maticu slovenskú a nejestvujúcu akadémiu vied. Jej úsilie zbierat' a prezentovat' vzácne artefakty minulosti slovenského národa vyústilo v roku 1907 do otvorenia spolkového múzea. Slovenské národné múzeum v Martine sa postupne stalo centrom vedeckého života, $\mathrm{k}$ čomu prispievali aj jeho archívne fondy. Archív patril od počiatku k prvým profesionálnym pracoviskám na Slovensku, kde sa vykonávala systematická archívna činnost'. Nezastupitel'nú rolu pri jeho budovaní zohrala archivárka - jedna zo zakladatel'ských osobností moderného slovenského archívnictva - Mária Jeršová Opočenská. Počas tridsat' rokov praxe v SNM získavala a ochraňovala vzácne písomné pramene, ktoré spracúvala

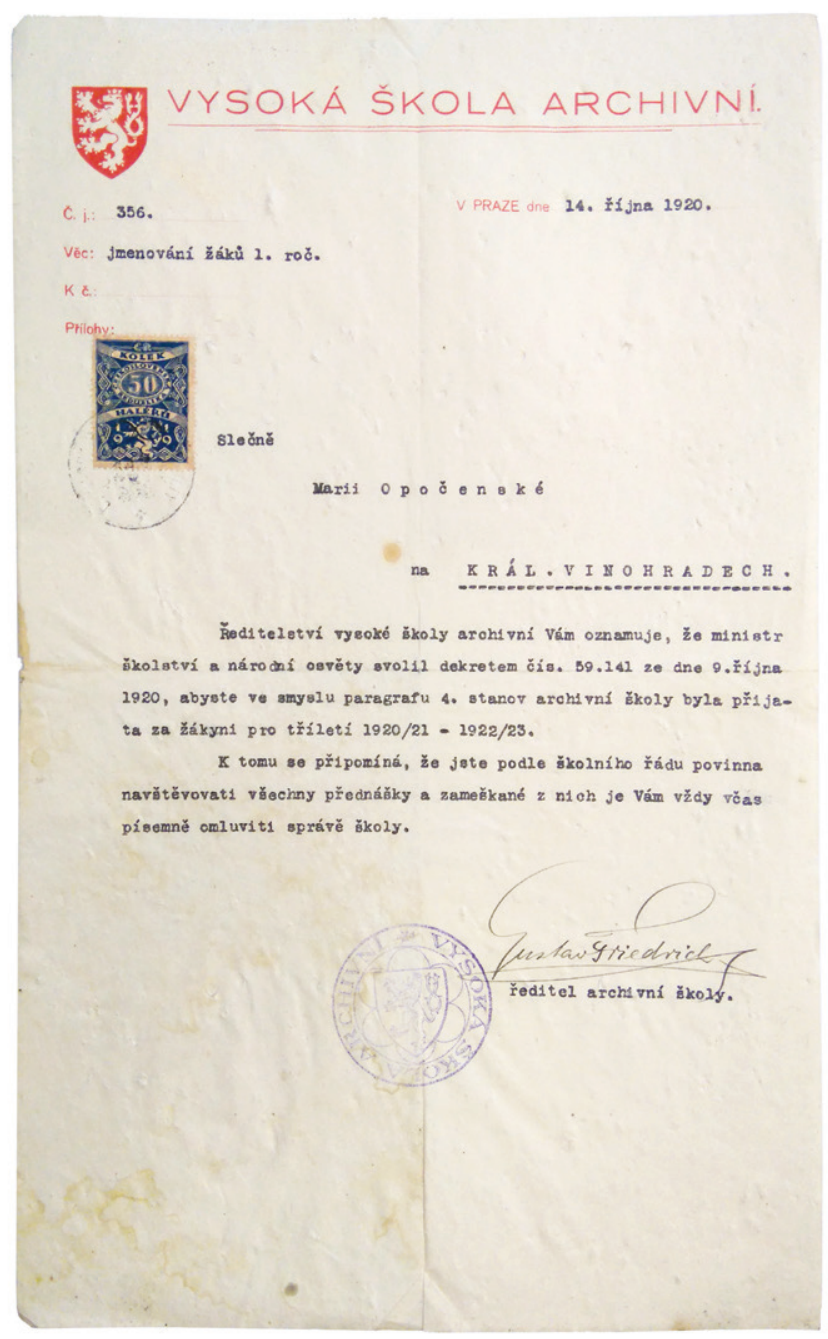

Obr. 4. Rozhodnutie o prijatí Márie Opočenskej za žiačku Vysokej školy archívní, Praha 14. októbra 1920. Archív SNM, pobočka v SNM-Múzeách v Martine. Fond M. Jeršová, sign. MJ/I.

prostredníctvom moderných metodických postupov a sprístupňovala ich bádatel’om prvými tlačenými archívnymi pomôckami. Výsledkami svojej odbornej práce a l’udskej obetavosti sa vel'kou mierou zaslúžila o vytváranie archívneho aj múzejného bohatstva na Slovensku, jej zásluhy d'aleko presiahli inštitucionálny a regionálny rozsah.

\section{Pred príchodom do Martina}

Mária Opočenská bola rodáčkou z Prahy, narodila sa 11. júla 1899. ${ }^{6}$ Po maturite v roku 1918 sa rozhodla pre históriu a filozofiu na Karlovej univerzite (1918-1922). ${ }^{7}$ Ešte počas štúdia histórie začala navštevovat' M. Opočenská novozriadenú Štátnu školu archívnu (1920-1923). ${ }^{8}$ V roku 1923 po obhájení dizertačnej práce a zložení rigoróznej skúšky

\footnotetext{
${ }^{4}$ Elena MachaJDíKovÁ, Slovenské národné múzeum a jeho predchodcovia v Bratislave počas druhej svetovej vojny alebo Inter arma silent musaea, in: Múzeá vo vojne. Druhá svetová vojna a jej dôsledky na činnost' múzeí a ich zbierky. Zborník príspevkov z odbornej konferencie, Múzeum Slovenského národného povstania Banská Bystrica, 10.-11. november 2015, s. 17.

5 E. KráliKovÁ, Významné medzníky, s. 25-34.

${ }^{6}$ Archív Slovenského národného múzea (d’alej Archív SNM), pobočka v SNM-Múzeách v Martine, fond (d’alej f.) Mária Jeršová, sign. MJ/1; Curiculum vitae, Praha 15. decembra 1926.

7 Archív SNM, pobočka v SNM-Múzeách v Martine, f. Mária Jeršová, sign. MJ/1, Index.

8 Archív SNM, pobočka v SNM-Múzeách v Martine, f. Mária Jeršová, sign. MJ/1. M, Vysvedčení o státní skoušce archívni. Jeršová je absolventkou II. kurzu (1920-1923).
} 

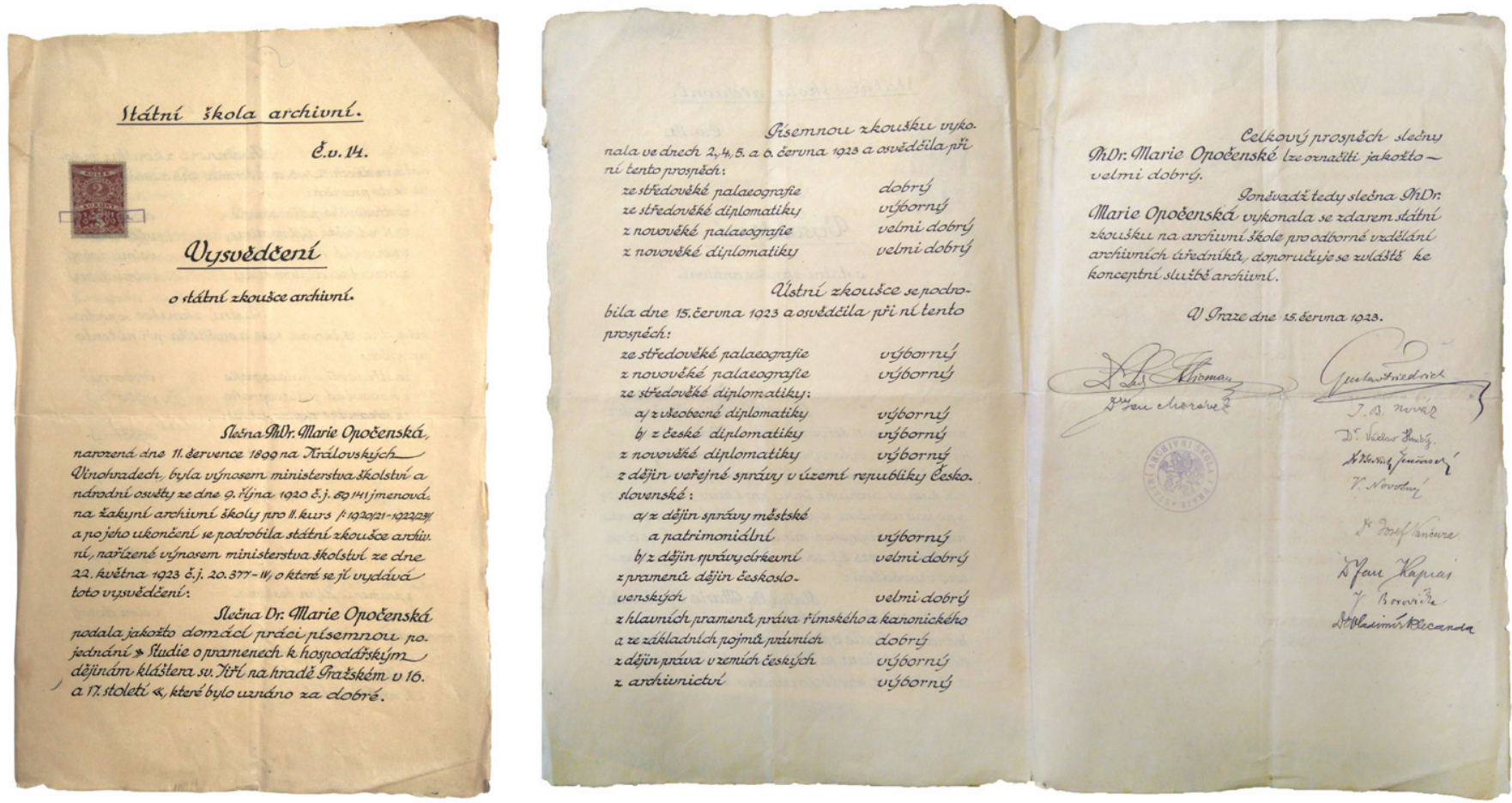

Obr. 5. Vysvedčenie Márie Opočenskej o štátnej archívnej skúške. Praha 15. júna 1923. Archív SNM, pobočka v SNM-Múzeách v Martine. Fond M. Jeršová, sign. MJ/I.

bola promovaná za doktorku filozofie a úspešne ukončila aj štúdium na archívnej škole prácou: Studie o pramenech k hospodářským dějinám kláštera sv. Jiři na hradě Pražském v 16. a 17. století a získala ,vysvedčenie spôsobilosti na archívnu službu“".

Svoju pracovnú kariéru začala v pražských archívoch, v Archíve Národního musea v Prahe, neskôr nastúpila do Zemského archívu českého a krátko pracovala v Československom historickom ústave. ${ }^{9}$

Vážny záujem o archívne pramene k dejinám Slovenska ju v rokoch 1924-1925 zaviedli do Ríma. Počas štipendijného pobytu sústred'ovala slovaciká z obdobia pontifikátu Klementa VI. vo vatikánskych archívoch do edície Monumenta Vaticana Slovaca. V nasledujúcom roku už smerovali jej kroky na Slovensko. Na základe poverenia Václava Chaloupeckého, štátneho inšpektora archívov a knižníc na Slovensku pracovala krátky čas na súpise stredovekých listín v Mestskom archíve v Košiciach. Onedlho odišla na štipendijný pobyt do Viedne. Výsledkom jej skúmania archívnych prameňov súvisiacich $\mathrm{s}$ dnešným územím Slovenska vo Viedni sa stala práca Slovenika uhorských listín v domácim dvorním a státním archivu vo Vídni v obdobi let 1243-1490, ktorá vyšla vo vydavatel'stve Orbis v Prahe roku 1927. Menej úspešné bolo zavŕšenie jej pracovného nasadenia pri spracúvaní pozostalosti Adama Františka Kollára, riaditel'a Dvorskej knižnice vo Viedni, pretože jej súpis prameňov a dielo ostali len $v$ rukopise. ${ }^{10}$

\section{Budovanie Archívu SNM}

Po návrate uspela M. Opočenská v konkurze na miesto archivárky Muzeálnej slovenskej spoločnosti v Turčianskom Sv. Martine. Archív existoval už od roku 1907, ale profesionálne archívne pracovisko vzniklo až 1. júna 1929 príchodom Márie Opočenskej - archivárky s univerzitným vzdelaním. ${ }^{11} \mathrm{~S}$ jej menom sú spojené začiatky a rozkvet nielen martinského, ale aj slovenského archívnictva vôbec.

Archivárka spracúvala a sprístupňovala archívne fondy a archívne zbierky v Slovenskom národnom múzeu v Martine, ktoré sa stalo jej celoživotným pracoviskom. Svoje pôsobenie $\mathrm{v}$ archíve začala predovšetkým zabezpečením postavenia a vybavenia archívu. Jej hlavným zameraním bolo získavat', spracúvat' a ,zachraňovat' $i$ archívne pamiatky nedostatočne uložené a spracované, prijímat' ako depozitum a odborne riadit archivy spolkové, rodové, súkromné, korešpondenciu a pozostalosti vynikajúcich slovenských spisovatel'ov, učencov a politikov slovenských a opatrovat' archív Národnej rady slovenskej. Podnikat'výskumné práce $v$ archivoch slovenských i zahraničných, ich výsledky ukladat'v archíve a za istých podmienok dávat' ich $k$ dispozícii bádatel'om." ${ }^{\text {12 }}$

Archivári majú nezastupitel'nú úlohu pri budovaní archívnych fondov, aj ich sprístupňovaní, najmä pre svoje úsilie a schopnost' sústredit' archívne bohatstvo a vyt'ažit' z jeho informačnej databázy maximum. Aj M. Opočenská

\footnotetext{
9 Archív SNM, pobočka v SNM-Múzeách v Martine, f. Mária Jeršová; sign. MJ/1; Curiculum vitae, Praha 15. decembra 1926.

${ }^{10}$ Archív SNM, pobočka v SNM-Múzeách v Martine, f. Mária Jeršová; sign. MJ/1; Curiculum vitae, Praha 15. decembra 1926.

${ }^{11}$ Elena MachajdíkovÁ, Sprievodca po Archive Slovenského národného múzea, Bratislava 2008, s. 26.

${ }^{12}$ Postavenie archívu špecifikovala vyhotovením „Štatútu Archívu SNM v Turčianskom Sv. Martine“ a archívnym, respektíve bádatel’ským, poriadkom. Schválené normy určovali hlavné zameranie archívu.
} 
sprístupňovala archívne pramene, napríklad listiny miest, mestečiek a zemianskych rodín z Turca i blízkeho okolia v pramennej edícii Slovenský diplomatár. Vychádzal v Sborníku MSS v rokoch 1931-1936. ${ }^{13} \mathrm{~K}$ otázkam slovenského archívnictva a múzejníctva sa zase vyjadrovala v štúdiách, odborných článkoch a recenziách na stránkach rôznych periodík, ako bol Zborník Matice slovenskej, Časopis Muzeálnej slovenskej spoločnosti, Zborník Muzeálnej slovenskej spoločnosti a iné.

V súkromnom živote stretla Mária svojho životného partnera Vladimíra Jonoviča Jeršova, vzdelaného dobrodruha, vraj s neobyčajným šarmom, s ktorým uzavreli manželstvo v roku 1931 (28. februára). ${ }^{14}$

Turiec M. Jeršovej učaroval svojou krásnou prírodou a bohatou históriou. Prehl'ad o turčianskych zemianskych rodinách získavala z archívnych dokumentov pri ich spracúvaní. Zozbierala jednotliviny i celé archívy. Niektoré archívy zemianskych rodín z Turca boli pred vznikom ČSR odvezené do Budapešti, napríklad i archív Ivankovcov z Jordánu a Dražkoviec. Jeršovej sa ho podarilo získat' spät' do Turca už len vo fotokópiách. S finančnou pomocou bratislavského advokáta Milana Ivanku vyšla v roku 1937 v tlačiarni Karla Kryla v Novom Jičíne Jeršovej monografia Rod Ivánka z Jordánu a Dražkoviec. Autorka v nej spracúva dejiny zemianskej rodiny na pozadí hospodársko-spoločenského vývinu Turca. Toto jej priekopnícke historicko-genealogické dielo vynikalo precíznym odborným spracovaním, obsahovalo totiž aj diplomatár listín turčianskej a novohradskej vetvy rodu, súpis rukopisov rektora a spisovatel'a Samuela Ivanku z Necpal pri Martine, genealogické tabul'ky a mapy. ${ }^{15}$

$\mathrm{V}$ archíve sa $\mathrm{v}$ tomto období nachádzali okrem archívneho fondu vlastnej inštitúcie a Muzeálnej slovenskej spoločnosti, aj archívy spolkov, feudálnych rodov, panstiev a šl'achtických rodín, cechov, škôl, súkromné pozostalosti

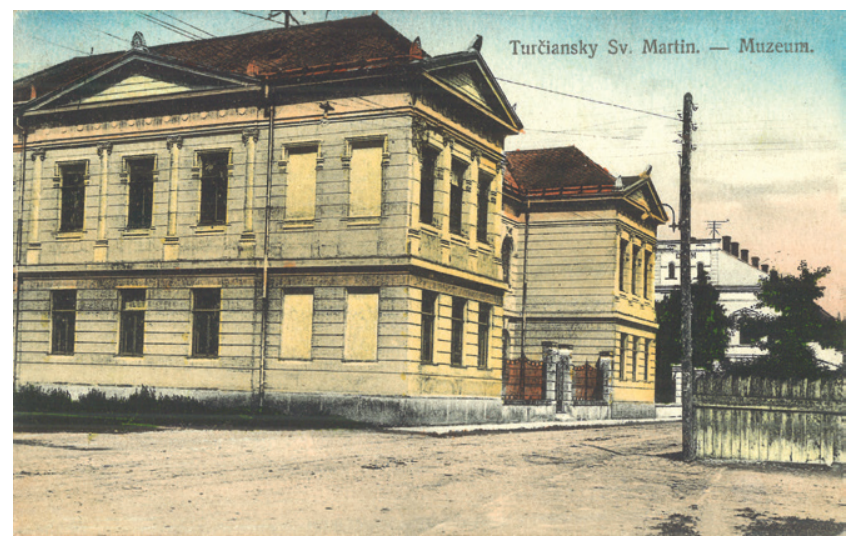

Obr. 6. Budova Slovenského národného múzea v Turčianskom sv. Martine, zač. 20. storočia.

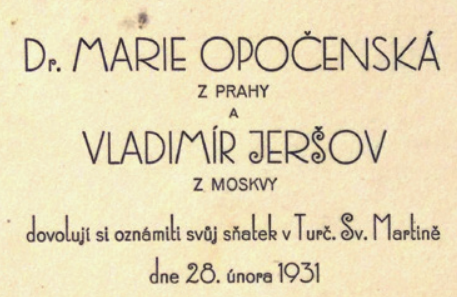

Obr. 7. Svadobné oznámenie Márie Opočenskej a Vladimíra Jeršova. Martin 28. februára 1931. Archív SNM, pobočka v SNM-Múzeách v Martine. Fond M. Jeršová, sign. MJ/I.

a korešpondencia - spisovatel'ov, učencov a politikov a iné. Medzi najcennejšie archívne zbierky na Slovensku v tom čase, patrila jej zbierka pergamenových listín rozličnej proveniencie z rokov 1255 až 1865 sprístupnená lístkovým katalógom. Rovnako ako zbierka rukopisov rozličnej proveniencie a povahy zo 16.-20. storočia. Pri spracúvaní, respektíve prepise listín, postupovala archivárka $\mathrm{v}$ súlade $\mathrm{s}$ transkripčnými zásadami, ktoré sama zostavila. ${ }^{16}$

M. Jeršová vytvorila i zbierky máp, pečatidiel, pečatí, rukopisných kancionálov a hudobnín, pohrebných veršov a kázní, patentov a nariadení, rôznych tlačív, fotografií a iné. V tomto pohnutom období obohatila archív o d’alšie významné prírastky, získala napríklad pozostalost' generála M. R. Štefánika, neskôr archív rodiny Kubínyi, archív spolku Živena, archív Turčianskej stolice a d'alšie. ${ }^{17}$ Závery zo svojich výskumov zverejňovala publikovaním v odborných štúdiách a článkoch vo viacerých odborných periodikách z oblastí archívnictva, múzejníctva ale i dejín poddanstva, šoltýskeho práva a národopisu. M. Jeršová sa zapísala do dejín archívov najmä vydaním archívnej pomôcky - Inventára Archívu Slovenského národného múzea v Turčianskom Sv. Martine, po prvýkrát v tlačenej podobe. Vydat' inventár knižnou formou jej umožnilo pražské vydavatel'stvo Melantrich v roku 1938, ktoré celý náklad financovalo a venovalo v prospech SNM. Inventár obsahoval údaje o dejinách pôvodcu, dejinách fondu, archívnu charakteristiku, údaje o edíciách, literatúre, ako aj podrobný opis listín. Jeršovej archívna pomôcka položila základy práce archivára s archívnymi fondmi. ${ }^{18}$ Práce na druhom zväzku inventára prerušili politické udalosti v rokoch 1938 a 1939 a nasledujúce vojnové roky. Autorsky ho archivárka pripravila, ale tlačou vyšiel až v roku 1953. ${ }^{19}$ M. Jeršová sa stala tiež spoluautorkou prvého

\footnotetext{
${ }^{13}$ Slovenský diplomatár I., in: Sborník MSS, roč. 25, Turčiansky Sv. Martin 1931, príloha s. 1-32; Slovenský diplomatár II. in: Sborník MSS, roč. 26, Turčiansky Sv. Martin 1932, príloha s. 33-48; Slovenský diplomatár III., in: Sborník MSS, roč. 27-28, Turčiansky Sv. Martin 1933-1934, príloha s. 49-64; Slovenský diplomatár IV., in: Sborník MSS, roč. 29, Turčiansky Sv. Martin 1935, príloha s. 65-80; Slovenský diplomatár V.; in: Sborník MSS, roč. 30, Turčiansky Sv. Martin 1936, príloha s. 81-100.

${ }^{14}$ Archív SNM, pobočka v SNM-Múzeách v Martine, f. Mária Jeršová, sign. MJ/1, Svadobné oznámenie.

${ }^{15}$ Elena Machajdíková, Prví genealógovia v Slovenskom národnom múzeu, in: Milan ŠIšmiš (ed.), K dejinám genealogického výskumu na Slovensku, Martin 2007, s. 47-52.

${ }^{16}$ Archív SNM, pobočka v SNM-Múzeách v Martine, f. Mária Jeršová, sign. MJ/15,Transkripčné pravidlá pre 15.-17. storočie.

${ }^{17}$ E. MachajdíkovÁ, Sprievodca po Archíve, s. 27.

${ }^{18}$ Mária OpočEnsKÁ-JERŠOvÁ, Inventár Archívu Slovenského národného múzea v Turčianskom Sv. Martine, Praha 1938.

${ }^{19}$ Elena MachajdíkovÁ, PhDr. Mária Jeršová Opočenská a Archív Slovenského národného múzea, in: Dejiny archívov na Slovensku, Bratislava 2008, s.127-140.
} 


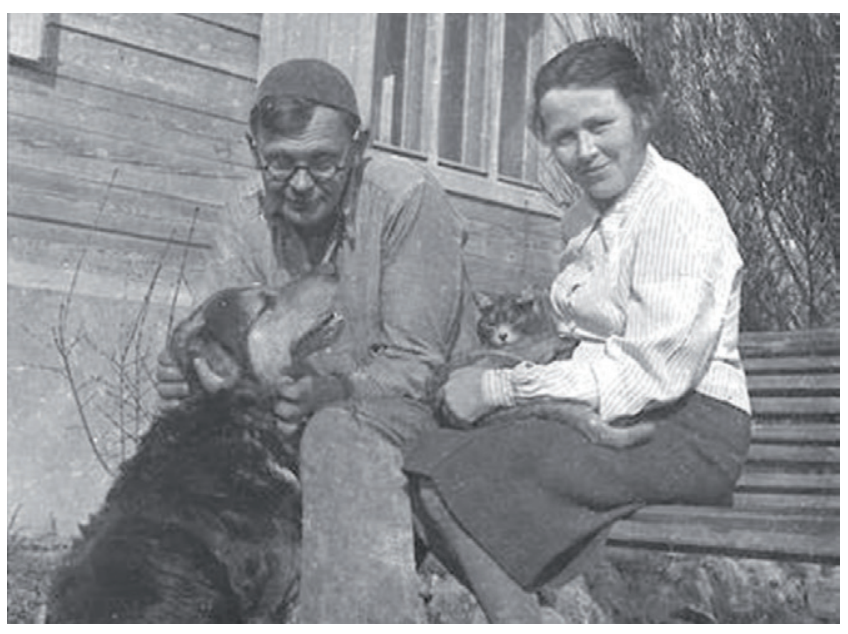

Obr. 8. Mária a Vladimír Jeršoví. Martin 50. roky 20. storočia. Archív SNM, pobočka v SNM-Múzeách $v$ Martine. Fond $M$. Jeršová, sign. MJ/l.

tlačeného Sprievodcu sbierkami múzea, ktorého autormi boli odborní kustódi jednotlivých fondov SNM, archív spracovala M. Jeršová. Podobne aj v tomto prípade, druhý zväzok vyšiel až o dve desat'ročia neskôr (v rokoch 1950-1952). ${ }^{20}$

\section{Archív SNM v období prvej Slovenskej republiky}

Po vzniku tzv. Slovenského štátu hrozilo Márii ako Češke vyst'ahovanie zo Slovenska. Viacerí kolegovia a známi sa manželov Jeršovcov zastali, a tak mohli v Martine ostat'.

Ako uvádza M. Jeršová vo svojom denníku, hned' po vyhlásení Slovenského národného povstania sa obaja manželia zapojili do protifašistického odboja, ukrývali ruských utečencov a pomáhali pri organizovaní partizánskeho hnutia v Turci. V. J. Jeršova v novembri 1944 zajali a odviezli do koncentračného tábora $\mathrm{v}$ Nemecku. ${ }^{21}$ Mária pomáhala zachraňovat' okrem l'udských životov i archívne pramene. Za dramatických okolností sa jej podarilo evakuovat' najstarší a najcennejší stredoveký materiál do Banskej Bystrice, Rakova i Mošoviec. ${ }^{22}$ Snažila sa nazhromaždit’ čo najviac materiálu k práve prebiehajúcim dejinným udalostiam. Vytvorila vel'kú zbierku dokumentačného materiálu, tlače, fotografií o Slovenskom národnom povstaní (d’alej len SNP) a oslobodzovaní. Archív SNM sa neskôr stal jej zásluhou dokumentačným centrom nielen pre výskum protifašistického odboja, ale aj najvyhl'adávanejším zdrojom pre výstavnú, publikačnú a prednáškovú činnost'.

\section{Po druhej svetovej vojne}

M. Jeršová posledné mesiace vojny prežila v Horných Obdokovciach. Po skončení vojny a príchode V. J. Jeršova zo zajatia, rozhodli sa manželia pre návrat do Martina.

Archivárka pripravila prvú výstavu o SNP, ilegálnom hnutí a odboji počas povstania, ktorú SNM sprístupnilo

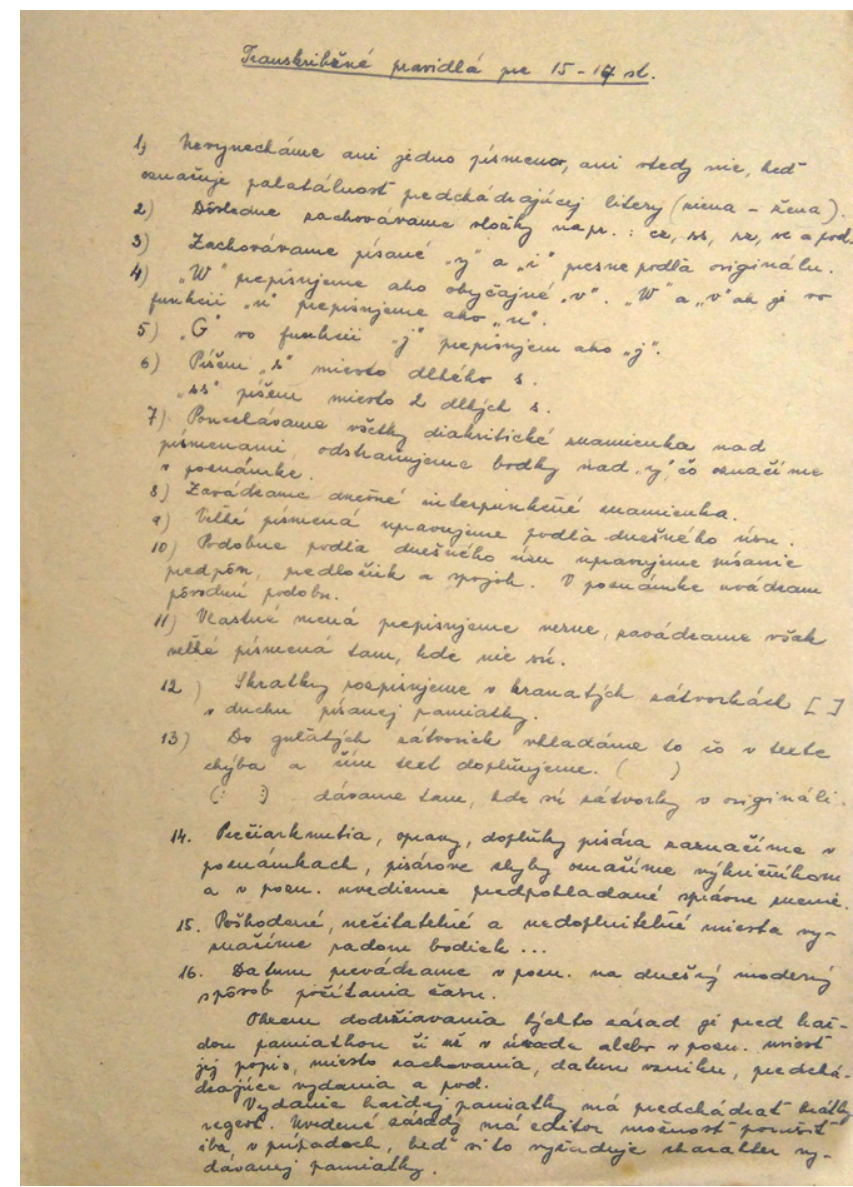

Obr. 9. Transkribčné pravidlá pre 15.-17. storočie. Autorka rukopisu je Mária Jeršová. Archív SNM, pobočka v SNM-Múzeách v Martine. Fond M. Jeršová, sign. MJ/15.

verejnosti už v auguste 1945. Za aktívnu účast' v SNP bola v rokoch 1945-1947 viackrát vyznamenaná (napríklad cenou SNP II. triedy a medailou za chrabrost'), napriek tomu však v roku 1947 jej Ministerstvo národní obrany zamietlo žiadost' „o priznanie charakteru československého partizána“, udelilo jej len d'akovný dekrét ,pomocnice“. ${ }^{23}$

Do záchrany archívov skonfiškovaných vel'kostatkov z Turca a východného Slovenska, najmä zo Spiša, sa hned' po skončení druhej svetovej vojny zapojila M. Jeršová aj z pozície členky Slovenského sboru pre otázky spojené $s$ reštitúciou kultúrnych materiálií, v ktorom pôsobila ako zapisovatel'ka a sekretárka. Slovenský sbor bol novozriadeným pomocným orgánom pri Ministerstve zahraničných vecí v Prahe (od 22. septembra 1945), ktorého činnost' sa sústredila najmä na vyhl'adávanie a kompletizáciu všetkých slovacík v mad'arských i viedenských inštitúciách a vytvorenie ich kompletných súpisov. Touto prácou boli poverení niektorí členovia zboru, vrátane Márii Jeršovej. Intenzívne sa podiel'ala na výskumoch, vytváraní súpisov, správ a podkladov na medzinárodné rokovania, ktoré mali za ciel' návrat násilne vyvezených kultúrnych pamiatok spät’ na územie Slovenska. ${ }^{24}$

\footnotetext{
${ }^{20}$ Sprievodca sbierkami Múzea, Turčiansky Sv. Martin, 1938.

${ }^{21}$ Archív SNM, pobočka v SNM-Múzeách v Martine, f. Mária Jeršová, sign. MJ/1, Denník

${ }^{22}$ E. Machajdíková, Sprievodca po Archíve, s. 29.

${ }^{23}$ Archív SNM, pobočka v SNM-Múzeách v Martine, f. Mária Jeršová, sign. MJ/2, Ocenenie.

${ }^{24}$ Elena MachajDíková, Kultúrne dedičstvo múzeí - reštitúcie po druhej svetovej vojne, in: Múzeá vo vojne. Druhá svetová vojna a jej dôsledky na
} 
Stála i pri založení Slovenskej historickej spoločnosti, ako uznávanú odborníčku ju zvolili do prvého výboru v roku 1946, v ktorom pôsobila jedno volebné obdobie (do roku 1950).

Udalosti februára 1948 bolestne zasiahli Jeršovcov, V. J. Jeršova zatkli v súvislosti procesom partizánskeho velitel'a Viliama Žingora a odsúdili na šest' rokov väzenia (1949). ${ }^{25}$

Február 1948 priniesol najmä celospoločenské zmeny a poštátnenie. Pre Slovenské národné múzeum v Martine začala nová etapa „boja o prežitie“. Do vyhlásenia zákona SNR č. 12/1949 o poštátnení, pôsobilo Slovenské národné múzeum od svojho vzniku ako spolkové múzeum spravované Muzeálnou slovenskou spoločnost’ou. Po roku 1948 muselo svoj vlastivedný charakter a zachovanie svojho zbierkového bohatstva obhájit'. Kustódi SNM, vrátane M. Jeršovej, úspešne ubránili svoju inštitúciu vecnou argumentáciou o vzniku a vývoji zbierok prednesenou na medzikrajskej porade v Kremnici v roku 1952.

\section{Pät'desiate roky 20. storočia}

Vd’aka M. Jeršovej vykazoval archív v 50. rokoch 20. storočia mimoriadne aktívnu, systematickú a odborne kvalifikovanú činnost'. Archívny fond sa jej poradilo obohatit' o množstvo cenných prameňov k dejinám Slovenska, napríklad: do správy archívu sa dostali v rámci reorganizačných opatrení viaceré skonfiškované rodinné archívy zemanov z územia bývalej Turčianskej župy. V roku 1953 vydala II. diel inventára, podiel'ala sa na vzniku novej expozície, najmä časti expozície z obdobia Vel'kej Moravy a feudalizmu i viacerých výstavách, venovala sa aj národopisnému výskumu Slovenska. Vedecky skúmala pramene k dejinám poddanstva, šoltýskeho práva, rybárstva a rybnikárstva, hrnčiarstva a keramiky, pláteníctva, súkeníctva a pod. Archív SNM sa $\mathrm{v}$ tej dobe stal jej zásluhou najvyhl'adávanejšou a najvýznamnejšou inštitúciou pre štúdium regionálnych aj národných dejín. $\mathrm{V}$ takejto podobe sa však nezachoval. Koncom 50. rokov 20. storočia po delimitácii sa mnohé jeho archívne fondy a zbierky stali súčast'ou niektorých novobudovaných štátnych archívov.

\section{Zrušenie archívu}

M. Jeršová dúfala, že vládne nariadenie s funkciou zákona č. 29/1954 Zb. o archívnictve upraví aj postavenie archívu, ale zmena priniesla zmarenie jej dovtedajšej práce. Novým zákonným predpisom vznikol Štátny slovenský ústredný archív, ktorý mal ochraňovat' archívne dokumenty celoslovenského významu. V praxi to znamenalo delimitáciu väčšiny fondov a zbierok, ktoré za 30 rokov do Archívu SNM archivárka získala a spracovala.

Napriek všemožnej snahe M. Jeršovej o záchranu archívu, bol Archív SNM v Martine zrušený s platnost'ou od

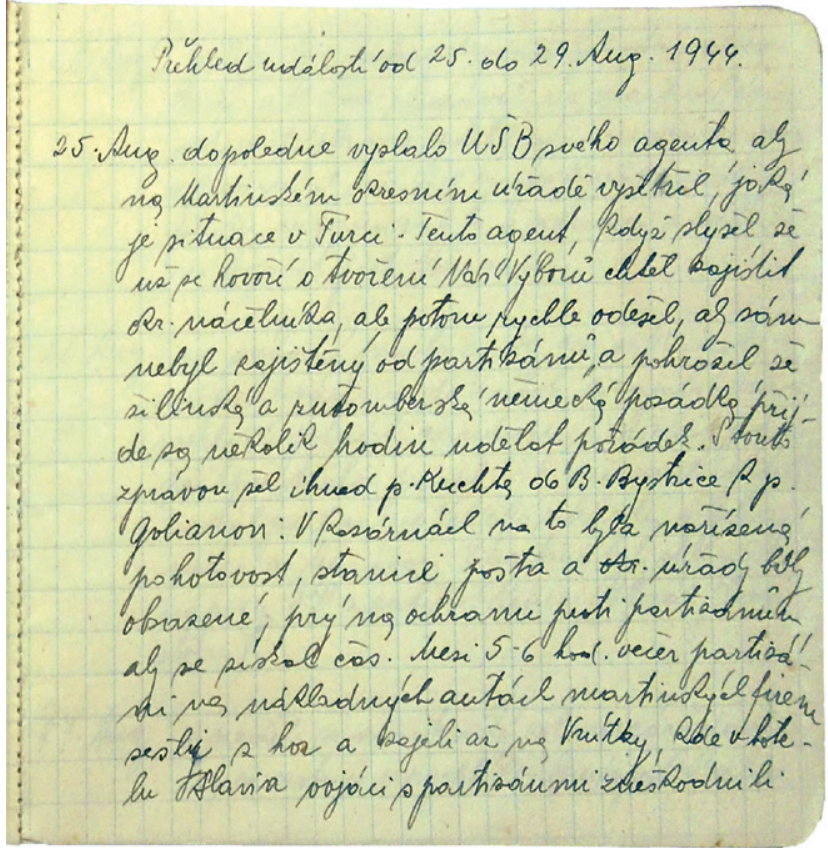

Obr. 10. Denník Márie Jeršovej so zápiskami zo Slovenského národného povstania (1944). Archív SNM, pobočka v SNM-Múzeách v Martine. Fond M. Jeršová, sign. MJ/20.

1. januára 1960. Neodpustitel'nú a negatívnu úlohu v celej záležitosti zohral vtedajší riaditel' SNM. ${ }^{26}$ Delimitácia medzi Povereníctvom vnútra a Povereníctvom školstva a kultúry, teda medzi archívmi a múzeami, prebehla na základe Uznesenia Zboru povereníkov č. 92/1959 Zb. V súlade s uznesením museli múzeá odovzdat’ archívom „dokumenty archívnej povahy“, napríklad pergamenové listiny, knihy, archívy cechov, archívy spolkov a spoločenstiev, mapy a plány, kroniky a pamätné knihy, pečatidlá, osobné archívy. Archívy mali zase recipročne múzeám vrátit’ „materiál múzejnej povahy“, teda trojrozmerné pamiatky. Väčšinu fondov a zbierok Archívu SNM prevzali vtedajší Štátny slovenský ústredný archív v Bratislave, Okresný archív v Martine, Štátny archív v Bytči a Literárny archív Matice slovenskej v Martine. ${ }^{27}$

M. Jeršová k 31. decembru 1959 rozviazala pracovný pomer, ale na delimitačné práce na prelome rokov 1959 a 1960 ešte osobne dozerala. ${ }^{28}$ Slovenské národné múzeum v Martine sa na základe zákona SNR č. 109/1961 Zb. o múzeách a galériách spojilo so Slovenským múzeom v Bratislave do jednej inštitúcie pod názvom Slovenské národné múzeum so sídlom v Bratislave, pričom jeho činnost' ostala orientovaná na artefakty národopisného charakteru.

Po odchode z múzea sa M. Jeršová aj nad’alej venovala výskumu a odbornej práci, aktívne sa zúčastňovala mnohých vedeckých podujatí, bola členkou viacerých profesionálnych spoločností. Za zásluhy a rozvoj Slovenského

činnost' múzeí a ich zbierky. Zborník príspevkov z odbornej konferencie, Múzeum Slovenského národného povstania Banská Bystrica, 10.-11. november 2015 , s. 88 .

${ }^{25}$ Nepomohli žiadosti o milost’ ani žiadne iné pokusy o oslobodenie, ktorými sa M. Jeršová snažila odsúdených zachránit’. V. J. Jeršova v zlom zdravotnom stave prepustili v roku 1953. Zvyšok trestu mu prezident republiky odpustil v roku 1961, ale úplnej rehabilitácie sa nedožil. Zomrel 5. septembra 1968 a je pochovaný vedl'a svojej manželky na cintoríne v Bystričke pri Martine.

${ }^{26}$ Archív SNM, pobočka v SNM-Múzeách v Martine, f. Mária Jeršová, sign. MJ/20, List M. Jeršovej Slovenskej archívnej správe z 5. marca 1959.

${ }^{27}$ Archív SNM, pobočka v SNM-Múzeách v Martine, f. Mária Jeršová, sign. MJ/20, Delimitačné protokoly a podklady k nim.

${ }^{28}$ Archív SNM, pobočka v SNM-Múzeách v Martine, f. Mária Jeršová, sign. MJ/20, List M. Jeršovej Slovenskej archívnej správe z 5. marca 1959. 


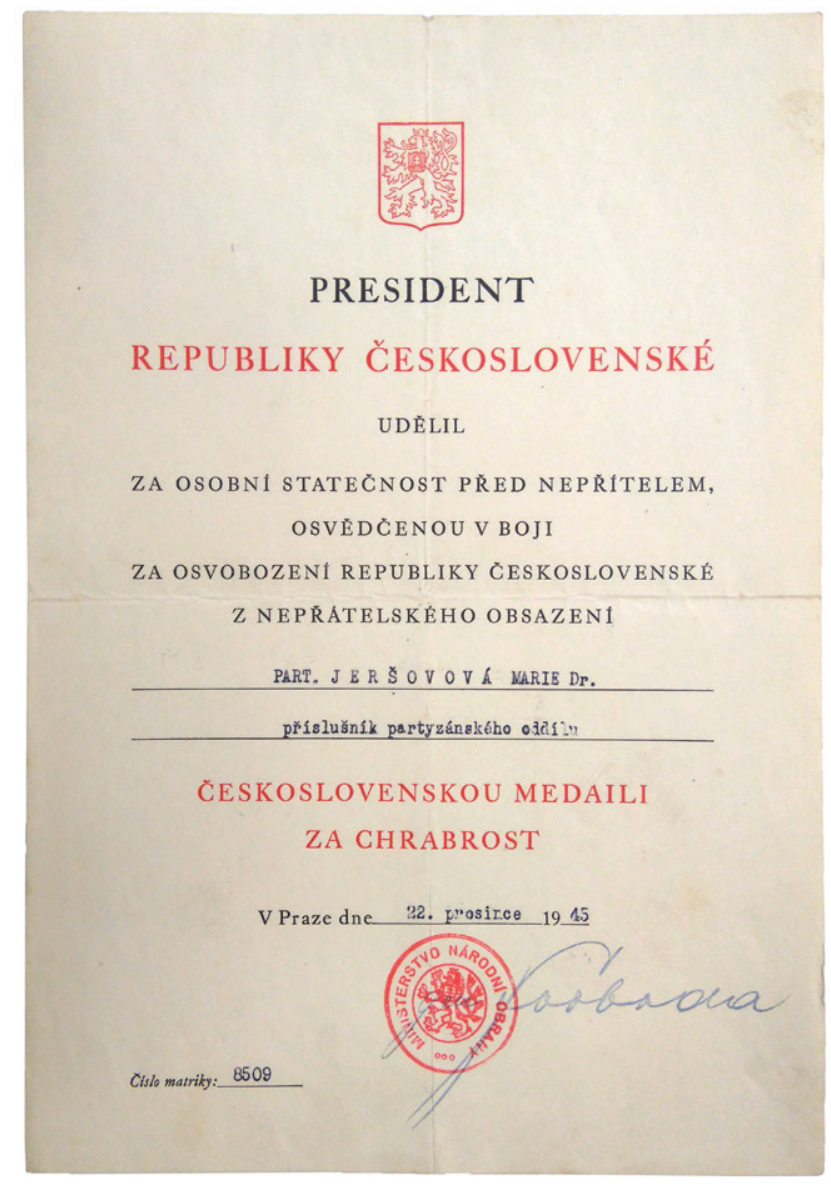

Obr. 11. Diplom za osobnú statočnost' ... udelený Márii Jeršovej prezidentom republiky armádnym generálom Ludvíkom Svobodom, 22. decembra 1945. Archív SNM, pobočka v SNMMúzeách v Martine. Fond M. Jeršová, sign. MJ/2.

národného múzea bola v roku 1968 ocenená striebornou medailou Muzeálnej slovenskej spoločnosti. ${ }^{29}$ Po smrti manžela (1968) odišla v roku 1969 bývat' k svojej sestre do Prahy. Zomrela 14. februára 1978, po smrti bola prevezená na cintorín v Bystričke pri Martine. ${ }^{30} \mathrm{O}$ miesto odpočinku Jeršovcov sa stará SNM v Martine.

Pražská rodáčka M. Jeršová sa zaslúžila o vznik a rozvoj Slovenského národného múzea a archívov Slovenska. Zasvätila svoju prácu záchrane archívnych prameňov. Výsledky práce tejto neobyčajne tvorivej a pokrokovej archivárky ostanú trvalým vkladom pri budovaní slovenského múzejníctva a archívnictva. Reorganizáciou Archívu SNM v Martine, jeho delimitáciou a odchodom M. Jeršovej do dôchodku sa ukončila staršia etapa dejín slovenského archívnictva.

\section{Archív po odchode M. Jeršovej}

Archív po odchode M. Jeršovej pričlenili ku knižnici, v SNM zostala už len registratúra MSS a SNM, národopisný a folkloristický materiál z Matice slovenskej, výskumné a cestovné správy. So systemizovaným miestom archivára sa nepočítalo. V rokoch 1967-1968 niektoré archívne práce vykonávali viacerí pracovníci. Archívne fondy a zbierky sa začali opät' systematicky doplňovat' až v roku 1977, kedy bolo obsadené systemizované miesto archivára. V tom čase už archív získal pozostalosti významných osobností, napríklad Martina Benku, Márie Jeršovej a jej manžela V. J. Jeršova, Jána Geryka, Andreja Polonca, Anny Horákovej-Gašparíkovej a iné dokumenty $\mathrm{k}$ národopisným zbierkam múzea.

Zriadenie archívu sa očakávalo aj v novobudovanom Zemedelskom múzeu v Bratislave v 30. rokoch 20. storočia. Architekt Milan Michal Harminc naprojektoval depozitár archívu do suterénu budovy. Správca (neskôr riaditel') Miloš Jurkovič začal budovat' archív podl'a vzoru M. Jeršovej a do múzea získal zaujímavé a hodnotné pramene. Budovanie archívu v Zemedelskom múzeu v tom čase nebolo však koncepčné, ani legislatívne a personálne doriešené. O archíve v modernom zmysle slova môžeme hovorit' až od roku 1974, kedy rozhodnutím Archívnej správy Ministerstva vnútra SSR č. 1117/24-74 (predchodca dnešného Odboru archívov a registratúr MV SR) sa nanovo úradne konštituoval Archív SNM so sídlom v Bratislave. Začala sa d’alšia etapa jeho činnosti so systematickým odborným spracovávaním a sprístupňovaním archívneho fondu.

Archív SNM patrí v sieti archívov na Slovensku do skupiny špecializovaných archívov Slovenskej republiky. Organizačne sa archív člení na ústredie so sídlom v Bratislave a pät' pobočiek. ${ }^{31}$ Jeho hlavným ciel'om je budovat' a ochraňovat' archívne fondy a archívne zbierky, odborne a vedecky ich spracovávat' a sprístupňovat' na vedecké a iné účely. Vzhl'adom na osobitné postavenie a mimoriadny význam Slovenského národného múzea je jeho archívne bohatstvo špecifické, rozmanité a pestré, obsahuje archívne dokumenty od konca 14. storočia do súčasnosti. Archív SNM preberá, darom a kúpou buduje archívne fondy a archívne zbierky pre poznanie dejín Slovenka a Slovákov $\mathrm{s}$ dôrazom na dejiny Slovenského národného múzea, jeho predchodcov, významných osobností a dejín múzejníctva na Slovensku vôbec. Medzi najvzácnejšie pamiatky patria, napríklad z hl'adiska slovenskej národnej histórie, dokumenty vyhlásené uznesením vlády SSR z 11. mája 1988 č. 126 za národné kultúrne pamiatky (d’alej len NKP), rukopisná konečná verzia 12-stránkového textu programového dokumentu slovenských štátoprávnych, politických a kultúrnych požiadaviek s názvom Memorandum národa slovenského k Vysokému snemu krajiny uhorskej, obsahujúce žiadosti národa slovenského, ciel'om spravodlivého prevedenia a zákonom krajinským zabezpečenia rovnoprávnosti národnej $v$ Uhrách, kroz narodnie slovenské shromaždenie v Turčianskom Sv. Martine dňa 6. a 7. junia roku 1861. Ďalšou NKP je rukopis rezolúcie zhromaždenia 1. mája 1918 v Liptovskom Mikuláši, obsahuje požiadavku uzavretia mieru, uznania práva na sebaurčenie národov Rakúsko-Uhorska, a teda aj pre „uhorskú vetvu československého kmeňa“, zavedenie všeobecného, rovného a tajného volebného práva, slobody slova a tlače a protest proti cenzúre slovenskej tlače. Po prvý raz v histórii v mene slovenského národa bola verejne

\footnotetext{
${ }^{29}$ Archív SNM, pobočka v SNM-Múzeách v Martine, f. Mária Jeršová, sign. MJ/20, Diplom a medaila MSS.

${ }^{30}$ Archív SNM, pobočka v SNM-Múzeách v Martine, f. Mária Jeršová, sign. MJ/1, Parte.

${ }^{31}$ V SNM - Múzeách v Martine (1976); SNM - Múzeu Červený Kameň (1979-1991; 1. 5. 1995); SNM - Múzeu Betliar (1. 7. 1996); SNM - Múzeu Bojnice (30. 6. 1988-31. 12. 1991; 1. 7. 1996); SNM - Spišskom múzeu v Levoči (1. 4. 2002).
} 


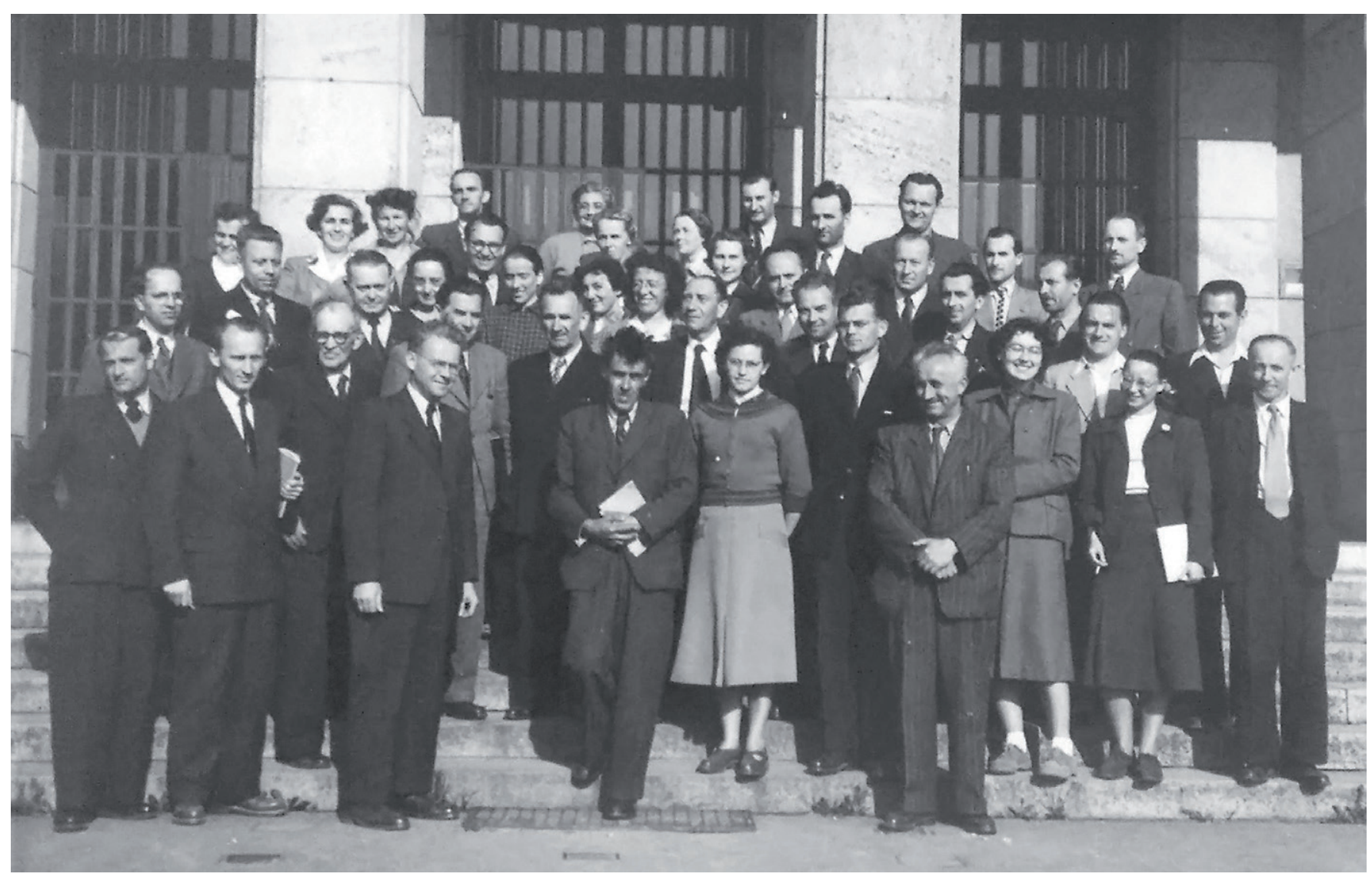

Obr. 12. I. celoštátna pracovná konferencia múzejníkov- etnografov. Martin 25.-27. 5. 1954. Archív SNM, pobočka v SNM-Múzeách v Martine. Fond M. Jeršová, sign. MJ/I.

vyjadrená požiadavka vybudovat’ československý štát. Rezolúcia odznela a bola prijatá 1. mája 1918 na zhromaždení sociálnodemokratickej strany v Liptovskom Mikuláši.

Archív SNM zostáva významnou zložkou SNM, ale i špecializovaným archívnym pracoviskom v sieti archívov na Slovensku. Jeho archívny fond tvoria okrem fondu vlastnej inštitúcie aj d’alšie pramene k dejinám múzejníctva, múzejných a kultúrno-umeleckých spolkov, osobné fondy významných osobností z oblasti vedy, spoločenského a kultúrneho života a rozličné zbierky, napríklad cechových dokumentov, listín, historických máp, kalendárov, pohl'adníc a d'alších.

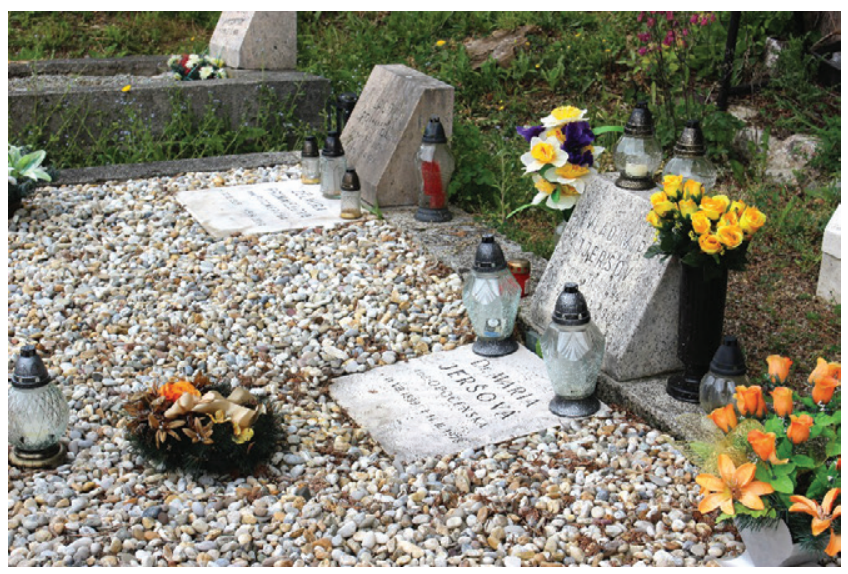

Obr. 13. Hrob Márie Jeršovej v Bystričke pri Martine, foto autorka. 